Published in final edited form as:

Hum Genet. 2009 July ; 126(1): 91-99. doi:10.1007/s00439-009-0701-2.

\title{
Genetics of alcohol dependence
}

\author{
Joel Gelernter and \\ Department of Psychiatry, VAMC 116A2, Yale University School of Medicine, 950 Campbell \\ Avenue, West Haven, CT 06516, USA. Department of Genetics, Yale University School of \\ Medicine, New Haven, CT, USA. Department of Neurobiology, Yale University School of \\ Medicine, New Haven, CT, USA. VA Connecticut Healthcare System, West Haven, CT, USA \\ Henry R. Kranzler \\ Department of Psychiatry, University of Connecticut School of Medicine, Farmington, CT, USA \\ Joel Gelernter: joel.gelernter@yale.edu
}

\begin{abstract}
Alcohol dependence (AD), a genetically influenced phenotype, is extremely costly to individuals and to society in the United States and throughout the world, contributing to morbidity and mortality and a host of economic, interpersonal, and societal problems. Although until recently the only genes established to affect risk for AD were those encoding several alcohol metabolizing enzymes, there are now several other genes that can be regarded as confirmed risk loci, discovered through linkage and candidate gene association studies. While the mechanism of action of the effects of alcohol-metabolizing enzymes on AD risk is thought to be well understood, we are still in the early stages of understanding the physiology of other risk loci. Further, it is clear that only a small number of the many genes that influence risk for AD have been identified. Newer methodologies (e.g., genomewide association, study of copy number variation, and deep sequencing of candidate loci to identify rare risk variants) that have improved our understanding of other complex traits hold the promise of identifying a greater set of AD susceptibility loci.
\end{abstract}

\section{Introduction}

Alcohol dependence (AD) is extremely costly to individuals and to society in the United States and throughout the world, contributing to morbidity and mortality and a host of economic, interpersonal, and societal problems. Although until recently the only genes established to affect risk for $\mathrm{AD}$ were those encoding several alcohol metabolizing enzymes, there are now several other genes that can be regarded as confirmed risk loci (GABRA2; Edenberg et al. 2004; Covault et al. 2004; Lappalainen et al. 2005; Fehr et al. 2006), or strong candidates based on published data (e.g., CHRM2, Wang et al. 2004; Luo et al. 2005a, b, c, GABRG1, Covault et al. 2008; Enoch et al. 2009). Although the mechanism of action of the effects of alcohol-metabolizing enzymes on AD risk is thought to be well understood, we are still in the early stages of understanding the physiology of other risk loci. Further, it is clear that only a small number of the many genes that influence risk for $\mathrm{AD}$ have been identified. However, genomewide association and other new methodologies hold the promise of identifying a greater set of $\mathrm{AD}$ susceptibility loci, as for many other complex traits.

\section{Heritability}

Genetic factors are important for the development of $\mathrm{AD}$, as established by the usual relevant methods of genetic epidemiology: twin, family, and adoption studies. Twin studies have generally yielded heritability estimates in the range of 50-60\% (e.g., Kendler et al. 1992, 1997; Prescott and Kendler 1999). We describe two illustrative studies that included 
large samples. Heath et al. (1997) studied AD risk in an Australian twin registry sample that included nearly 6,000 subjects. This study considered both male and female twins (like-sex and unlike-sex twin pairs), and found a consistent heritability of 64\%, using standard alcohol dependence diagnostic criteria. These investigators were also able to evaluate heritability by birth cohort, and found consistent values over a >20-year range of cohorts. Another notable study (Kendler et al. 1997) considered the intersection between the Swedish Twin Registry, which logged almost all twins born in that country from 1902 to 1949 (nearly 9,000 male pairs), and Swedish temperance board registrations from 1929 to 1974 (about 2,500 twins). Subjects came to the attention of temperance boards mostly because of alcoholism or crimes related to drinking. In this study, although the prevalence of temperance board registrations was similar in monozygotic (MZ) and dizygotic (DZ) twins, the concordance rate for such registration was significantly higher in MZ twins. Moreover, as in Heath et al. (1997) study, heritability was stable over time, suggesting that in this sample the environmental contributions to the risk for $\mathrm{AD}$ were also stable over time, and that major social and historical changes did not affect environmentally determined $\mathrm{AD}$ risk. Using tetrachoric correlation and model fitting, twin resemblance was attributed to genetic factors (54\%), family environment factors (14\%), and non-shared environmental factors (remainder). It is notable that such a complex and detailed analysis yielded results consistent with other studies of $\mathrm{AD}$, and over time within the study — using essentially ad hoc diagnostic criteria (i.e., temperance board registration). Thus, the diagnostic constructs used for $\mathrm{AD}$ for which genetic liability can be estimated appear to be valid and meaningful in terms of the consequences and outcomes for individuals.

However, genetic AD liability is not necessarily discrete; clinically, AD frequently cooccurs with other psychiatric disorders (especially other forms of substance dependence and antisocial personality disorder), and it has been demonstrated that at least some of this comorbidity is attributable to shared genetic liability. For example, AD shares genetic vulnerability with other externalizing disorders (conduct disorder, antisocial personality disorder, and drug dependence), and this common liability showed heritability of $80 \%$ (Hicks et al. 2004). Consistent with the notion of a general liability, AD has also been shown, specifically, to share genetic risk with nicotine dependence (ND) (Swan et al. 1997; True et al. 1999; Madden et al. 2000), and these traits also share genetic variance with caffeine use (Hettema et al. 1999). An obvious implication of these findings, which are based on twin samples, is that genes that influence risk for ND may also increase risk for $\mathrm{AD}$ and vice versa; this has been observed and several examples are discussed below.

\section{Genome-wide linkage studies}

Genome scan linkage mapping projects have identified promising chromosomal regions for AD susceptibility loci, some of which have led to the identification of disease-influencing loci. Linkage studies of AD published by the Collaborative Study on the Genetics of Alcoholism (COGA) group (Reich et al. 1998; Foroud et al. 2000) and by investigators in the Intramural Program of the National Institute on Alcohol Abuse and Alcoholism (NIAAA) (Long et al. 1998) yielded several chromosomal locations with lod scores suggesting that they harbor loci influencing risk for AD. Recruitment for COGA was conducted at six sites in the United States. Participants were ascertained from nuclear and extended pedigrees containing at least two alcohol-dependent first-degree relatives in addition to an alcohol-dependent proband. The NIAAA study ascertained participants from among members of a Southwestern American Indian tribe. Both groups reported data consistent with loci influencing risk for $\mathrm{AD}$ mapping in the vicinity of an alcohol dehydrogenase (ADH) gene cluster on chromosome 4q (see below). Several other linkage peaks, even those that did not meet standard criteria for genomewide significance, have led to the identification of likely disease-influencing loci. In addition, Wilhelmsen et al. (2003) 
reported a genomewide linkage study for the trait of low-level response to alcohol, which has been shown prospectively to increase risk for the development of AD (Schuckit 2009). Although this study involved a relatively small sample (139 sibling pairs chosen from among non-alcohol-dependent students attending two universities in San Diego, CA), several "suggestive" linkages were identified. Ehlers et al. (2004), in a linkage analysis using 791 microsatellite markers in 243 Mission Indians in the southwest United States, found several lod scores in excess of 2.0 for the phenotypes of alcohol severity (chromosomes 4 and 12) and alcohol withdrawal (chromosomes 6, 15, and 16). More recently, Prescott et al. (2006) reported on linkage analysis in a set of 474 small families recruited in Ireland. The strongest results from this study (up to a multipoint lod score of 4.59) were also on chromosome 4. In the only genomewide linkage study of AD in an African-American (AA) population, we found genomewide-significant linkage to markers on chromosome 10 (Gelernter et al. 2009).

\section{Candidate gene studies}

Both functional and positional candidate gene association approaches have been employed in studies of $\mathrm{AD}$, with notable successes achieved by both. Early studies focusing on functional candidates (e.g., $A L D H 2, A D H 1 B$ ) provided replicable specific gene effects on this complex behavioral phenotype. Influence of genetic polymorphism at some loci encoding acetaldehyde dehydrogenases and alcohol dehydrogenases on risk for AD in some populations is well established, and the mechanism is very clear. Alcohol is metabolized to acetaldehyde, a toxic intermediary, by alcohol dehydrogenases; acetaldehyde is metabolized primarily by acetaldehyde dehydrogenases, the most relevant of which is encoded by $A L D H 2$. Acetaldehyde produces a "flushing reaction" characterized by a set of uncomfortable symptoms including flushing of the skin, lightheadedness, palpitations, and nausea. A variant that reduces or eliminates ALDH function (occurring mostly in Asian populations) is protective against $\mathrm{AD}$ (because clearance of acetaldehyde is impeded), and $\mathrm{ADH}$ variants that increase function (and the production of acetaldehyde) may also be protective (see, e.g., Thomasson et al. 1991; Hasin et al. 2002; Konishi et al. 2003). Work with $A L D H 2$ provides an instructive and intuitive example of this work, as a variant common in Asians abolishes function of this gene and therefore has a very marked affect on acetaldehyde metabolism. A meta-analysis (Luczak et al. 2006) showed that subjects heterozygous for a null $A L D H 2$ allele have only about one-fourth the risk for alcohol dependence as those with two functional alleles.

Recently, the most fruitful work has focused on candidate genes that map within linkage peaks. Some of the best-supported AD risk loci map to two different regions of chromosome 4: an $\mathrm{ADH}$ gene cluster, which maps to the long arm, and a $\mathrm{GABA}_{\mathrm{A}}$ receptor subunit gene cluster, which maps to the short arm of the chromosome. As mentioned above, several genomewide linkage scans have implicated a region of chromosome $4 \mathrm{q}$ that contains an $\mathrm{ADH}$ gene cluster, and this prompted more intensive investigation of the ADHs. ADH4 (Luo et al. 2005a, b, 2006; Edenberg et al. 2006) is one of several disease-influencing loci in this cluster. Edenberg et al. (1999) demonstrated that the $-75 \mathrm{~A}$ allele, at a promoter polymorphic site in $A D H 4$, has promoter activity that is more than twice that of the $-75 \mathrm{C}$ allele. We reported strong associations of $A D H 4$ markers to $\mathrm{AD}$ using a range of methods, including Hardy-Weinberg disequilibrium analysis, structured association, and family based association (Luo et al. 2005a, b). We have also reported association to $\mathrm{AD}$ of numerous other loci in the ADH cluster (Luo et al. 2006).

Note that there is strong evidence of population-specificity for some very important alcohol metabolizing enzyme risk variants, e.g., a nonfunctional $A L D H 2$ variant mentioned briefly above that is confined to certain Asian populations, and an $A D H 2$ variant (rs2066702), 
traditionally called alcohol dehydrogenase- $2 * 3$, which encodes a high-activity isozyme that is common in AAs and rare in European Americans (EAs). Population specificity has been observed, although generally to a lesser degree, at some of the other loci discussed below. Thus it is already clear that risk variants are likely to be differentially important in different populations. Luczak et al. (2006) performed a meta-analysis of the effects of $A D H 1 B$ (as well as of $A L D H 2$, discussed above) in Asian populations, documenting robust effects on $\mathrm{AD}$ risk.

Other candidate gene hypotheses have generally related to genes that influence neurotransmission. $\gamma$-Aminobutyric acid (GABA) is the major inhibitory neurotransmitter in brain; alcohol exerts some of its effects via interaction with $\mathrm{GABA}_{\mathrm{A}}$ receptors. Allelic variants at loci participating in GABAergic neurotransmission have been convincingly associated with $\mathrm{AD}$ and related phenotypes. Porjesz et al. (2002) demonstrated, first, linkage of EEG $\beta$ frequency (a quantitative trait) to chromosome $4 \mathrm{p}$; then, $\mathrm{LD}$ to a $\mathrm{GABA}_{\mathrm{A}}$ receptor cluster, in a sample ascertained through pedigrees with multiple alcohol-dependent members. Fine mapping of this region showed allelic and haplotypic association to GABRA2 (Edenberg et al. 2004). We (Covault et al. 2004; Lappalainen et al. 2005), and others (Fehr et al. 2006) using case-control samples, replicated this major finding, with evidence of association of AD in three different populations. Enoch et al. (2006) and Soyka et al. (2008) replicated association to GABRA2, but their findings differed in the nature of the association and the specific variants that were associated with $\mathrm{AD}$, respectively. There have also been non-replications of the association (Drgon et al. 2006; Matthews et al. 2007), though these studies differed substantially from the other studies in the methods of phenotyping and ascertainment employed. The three samples studied by Drgon were ascertained from among polysubstance abusers and a small sample of primary alcoholics from COGA. Matthews et al. (2007) ascertained subjects using information from the diagnostic interview schedule, an unstructured clinician's interview, and family history report by participating relatives. They derived a "best-estimate" diagnosis based on Feighner criteria and DSM-III (which differs substantially from subsequent iterations of the DSM, the diagnostic systems used in the studies showing association to GABRA2).

Although the association is replicable, no specific causative variant has been reported, nor is a mechanism of action known. Interestingly, however, Pierucci-Lagha et al. (2005) found an allelic association of a $G A B R A 2$ allele with the subjective response to alcohol in a sample of healthy subjects. Further, Bauer et al. (2007) found that individuals with a GABRA2 allele associated with risk for $\mathrm{AD}$ in some studies had higher daily probabilities of drinking and heavy drinking in a longitudinal study of the psychotherapeutic treatment of the disorder. The polymorphism also moderated the response to the specific psychotherapies examined in the study. However, markers in the $3^{\prime}$ region of GABRA2 (which is the region associated) are in linkage disequilibrium (LD) with markers at the adjacent locus, GABRG1, in many populations, including EAs (Ittiwut et al. 2008; Covault et al. 2008). This raises the possibility that the $G A B R A 2$ association is driven at least in part by variants in $G A B R G 1$, with risk loci in both genes (Covault et al. 2008; Enoch et al. 2009).

Another report provided moderately strong support for the gene encoding the muscarinic acetylcholine receptor M2 (genetic locus CHRM2) as an AD risk locus (Wang et al. 2004). Like the ADH cluster loci and GABRA2, CHRM2 maps into a chromosomal region that was identified by an AD linkage study as being "of interest" (Reich et al. 1998). We replicated this finding (Luo et al. 2005c). There have been many other candidate gene studies in AD that we will not discuss in detail. For example, we (Luo et al. 2003) demonstrated a haplotypic association of OPRM1 (which encodes the $\mu$ opioid receptor) to the joint phenotype of $\mathrm{AD}$ and opioid dependence, and to $\mathrm{AD}$ (Zhang et al. 2006). A number of studies have also shown association of $\mathrm{AD}$ to the minor $(\mathrm{G})$ allele of an $\mathrm{A} 118 \mathrm{G}$ 
polymorphism in OPRM1, which encodes an amino acid substitution (Asn40Asp) in the extracellular portion of the $\mu$ opioid receptor. Although that polymorphism appears to be functional, there is controversy as to whether the change associated with the minor (Asp40) allele is a gain or loss of receptor function (Edenberg and Kranzler 2005). Further, multiple studies have shown association for the more common (Asn40) allele, and meta-analysis showed no overall association to substance dependence, including AD (Arias et al. 2006).

OPRM1 has also been evaluated as a moderator of the response to treatment with the opioid antagonist naltrexone. Ray and Hutchison (2007) used prospective genotyping to oversample individuals with the Asp40 allele for participation in a within-subject, doubleblind, placebo-controlled laboratory study evaluating the effects of pre-treatment with naltrexone or placebo on the response to an intravenous alcohol challenge session. Individuals with one or two Asp40 alleles reported lower levels of alcohol craving and greater alcohol-induced "high" across rising breath alcohol concentrations. Further, naltrexone blunted the positive response to alcohol, an effect that was stronger among individuals with the Asp40 allele.

Studies have also examined the moderating effect of the Asn40Asp SNP in OPRM1 on naltrexone treatment response in alcohol-dependent individuals and in samples of nontreatment-seeking heavy drinkers. Oslin et al. (2003), in a study of 130 EA subjects from three placebo-controlled trials, found that naltrexone-treated patients with one or more Asp40 alleles were significantly less likely than Asn40 homozygotes to relapse to heavy drinking. Placebo-treated subjects showed no moderating effect of genotype. Gelernter et al. (2007) examined the moderating effect of polymorphic variation in opioid receptor genes on treatment response in a subset of patients from the VA Cooperative Study of Naltrexone Treatment (Krystal et al. 2001). In addition to the Asn40Asp polymorphism, these investigators studied two other OPRM1 SNPs, three markers in OPRD1 (which encodes the delta-opioid receptor), and one marker in OPRK1 (which encodes the kappa-opioid receptor). They found no significant interaction between any of the SNPs studied and the response to naltrexone treatment. Anton et al. (2008) examined the moderating effect of the Asn40Asp SNP on the response to naltrexone treatment in a sub-sample of 297 EA subjects from the COMBINE Study (Anton et al. 2006). A positive moderating effect on the response to naltrexone was observed for carriers of the Asp40 allele on the percentage of heavy drinking days, with a robust effect on a global measure of treatment outcome. Kim et al. (2009) found a positive moderating effect of the Asp40 allele on time to relapse in a sample of 32 treatment-seeking Korean alcoholics.

In a brief cross-over trial of naltrexone versus placebo in a group of 30 non-treatmentseeking heavy drinkers, no difference in treatment response was observed for those with the Asp40 allele (Mitchell et al. 2007). Similarly, Tidey et al. (2008) found no moderating effect of the Asn40Asp SNP on drinking outcomes in a brief placebo-controlled trial of naltrexone in 173 non-treatment-seeking heavy drinkers.

Pharmacogenetic studies are often underpowered statistically due to the labor-intensive nature of treatment trials. Further, because the design features (including study samples and treatment outcome measures) of the various studies of OPRM1 have differed, the data are not amenable to meta-analysis. Although there appears, overall, to be a modest effect of the Asp40 allele on the response to naltrexone treatment in alcoholics, large, prospective studies are needed to estimate its magnitude more accurately.

Other than the set of alcohol metabolizing enzymes, the genetic locus probably most studied with respect to AD dopamine receptor (especially in the early 1990s) is the $\mathrm{D}_{2}$ locus, DRD2. Whether variation in this particular gene contributes to risk for alcoholism remains 
controversial. Reports of positive findings with what has been known historically as the DRD2 TaqI "A" system could be explained in terms of a small effect of polymorphic variation at this locus on risk, but it could also be explained in other ways, e.g., by population stratification or publication bias.

Interestingly, the variant that was initially proposed to be associated to alcoholism has been shown to map within the adjacent gene, $A N K K 1$ (Neville et al. 2004). DRD2 maps close to three other genes, in the order NCAM1/TTC12/ANKK1/DRD2. Based on the premise that observed weak and inconsistent $D R D 2$ association signals might be better explained through LD with another gene in this cluster (our initial hypothesis was that this might be the NCAM1 gene), we studied a set of 43 SNPs spanning this region. In our initial article (Gelernter et al. 2006), where the subjects were drawn from a cocaine and opioid dependence linkage sample, we found very strong evidence of association of ND with SNPs that map to a haplotype block that includes markers from $A N K K 1$ and TTC12. This region coincides with a linkage peak we observed for ND (Gelernter et al. 2006, 2007). We have since found similar evidence for association of AD to markers in the same haplotype block in a completely independent sample; in this case, the associated region centers on two TTC12 SNPs (Yang et al. 2007). The COGA group has reported consistent results for ANKK1 (they did not study TTC12) (Dick et al. 2007a). These studies provide an alternate explanation for the weak $D R D 2$ association reports that have surfaced regularly over the years-they may be explained by linkage disequilibrium with adjacent loci wherein map the actual risk alleles. Also, although investigators were led to this genomic region by a candidate gene hypothesis, our interpretation of all of the available data is that it was not the candidate gene that was driving the association. We have speculated, though, that the genes actually associated with phenotype may be functionally related to $D R D 2$.

\section{Genomewide association studies (GWASs)}

GWASs are a potentially more powerful alternative to linkage for locating genes without prior knowledge of physiology or disease pathophysiology. GWAS designs are unique in their potential to identify risk loci of relatively small effect (without prior hypothesis), much smaller than may be detected through linkage strategies. Further, linkage requires family sampling schemes, which create a bias towards detection of loci of relatively high attributable risk ratios; other loci may, however, be more important on a population level. The first GWAS for a specific SD trait (excluding studies that used a pooling methodology exclusively) examined ND (Bierut et al. 2007). A two-stage design was employed; first a study using pooled DNA was used to screen 2.4 million SNPs; second, >30,000 SNPs selected from the first stage were screened individually in 1,050 cases and 879 controls. Numerous genes were identified as possibly associated to ND, including both novel genes (e.g., neurexin 1, NRXN1, and vacuolar protein sorting 13 homolog A, VPS13A) and genes that were previously considered candidates based on known physiology (e.g., cholinergic receptor, nicotinic, alpha 5, CHRNA5). The latter finding has been confirmed in larger studies (see below). Subsequent GWAS studies demonstrated striking association between variation in the nicotinic receptor gene cluster CHRNA5-CHRNA3-CHRNB4 and ND and related traits (Berrettini et al. 2008; Thorgeirsson et al. 2008), as well as with lung cancer (Amos et al. 2008; Hung et al. 2008). These findings have implications for AD risk also.

\section{Nicotinic receptor cluster on chromosome 15}

Based on non-significant results in the GWAS of nicotine ND discussed above (Bierut et al. 2007) and significant results in three subsequent studies of ND and/or lung cancer (Thorgeirsson et al. 2008, Amos et al. 2008; Hung et al. 2008), a cluster of nicotinic receptor genes has emerged as a candidate region for phenotypes related to cigarette smoking. These 
variants also appear to modulate risk for several other forms of substance dependence, including AD. Although the discovery of the effect on ND-related traits is recent and there have been only a few articles to date examining the association of variation in nicotinic receptor genes and $\mathrm{AD}$ and related phenotypes, the findings from these studies are unusually consistent. Variants at this cluster have been associated to risk for AD (Wang et al. 2008), early initiation of alcohol use (Schlaepfer et al. 2008), and level of response to alcohol (Joslyn et al. 2008). The mechanism by which genetic variation in these genes might affect risk for $\mathrm{AD}$ is not yet clear, but in view of the known shared genetic liability between ND and $\mathrm{AD}$, the finding is not surprising.

\section{Gene-by-environment $(G \times E)$ interaction and alcohol dependence}

In view of the fact that the heritability of $\mathrm{AD}$ is in the range of $50-60 \%$, there is considerable environmental influence on the phenotype, as is the case for other complex traits. However, unlike many other such traits, environmental factors are a necessary component of $\mathrm{AD}$. One cannot become substance dependent without exposure to the substance, regardless of one's genetic constitution. This places a trait like AD in contrast to a trait like schizophrenia, which, so far as is known, does not require any special environmental exposure to develop. It has been appreciated only recently that $\mathrm{G} \times \mathrm{E}$ effects can be detected reliably for psychiatric traits and specific candidate loci using samples of a size that can feasibly be recruited (see Caspi and Moffitt 2006 for a review), whereas the impact of environmental factors on genetic risk of $\mathrm{AD}$ related to alcohol metabolizing enzymes has a longer history (e.g., Heath et al. 2001).

In a prospective-longitudinal study of a representative birth cohort, Caspi et al. (2003) reported that variation in a promoter-linked polymorphism in $S L C 6 A 4$, which encodes the serotonin transporter, moderated the influence of stressful life events on depressive symptoms, depression diagnosis, and suicidality. A similar $\mathrm{G} \times \mathrm{E}$ approach was used to examine the interaction between this 5-HTTLPR polymorphism and alcohol-related risk. To date, three studies have shown that the 5-HTTLPR "s" allele (which is associated with lower expression and functionality), in the context of various environmental stressors, is associated with increased alcohol consumption (Nilsson et al. 2005; Covault et al. 2007; Kaufman et al. 2007). This augments meta-analytic findings of a main effect of the s allele of 5-HTTLPR on risk of $\mathrm{AD}$ (Feinn et al. 2005). However, there are variable findings in relation to the $\mathrm{G} \times$ E effect. The COGA group (Dick et al. 2007b) failed to replicate a moderating effect of environmental stress on the association of this polymorphism with AD. Recently, a German group studying participants in the Mannheim study of children at risk (Laucht et al. 2009), a cohort of individuals being followed from birth into young adulthood, found that, when exposed to high psychosocial adversity, individuals homozygous for the higher expression 1 allele reported more hazardous drinking than those with an s allele or those without exposure to adversity. Although the effect was confined to males, it was consistent across different types of adversity.

The activity of the hypothalamic-pituitary-adrenal (HPA) axis, an important mediator of the stress response (see Clarke et al. 2007 for a review) is of interest in relation to the effects of environmental stress on the level of alcohol consumption and the risk of AD. CRHR1, which encodes the corticotrophin releasing hormone receptor 1 , has been evaluated as a candidate locus moderating the effects of stress on alcohol consumption. Treutlein et al. (2006) found that two haplotype tagging SNPs (rs242938, rs1876831) in CRHR1 were associated with binge drinking in two independent samples: the Mannheim adolescent sample and a sample of alcohol-dependent adults. Blomeyer et al. (2008) extended these findings by examining the interaction effects on drinking of these variants and life stress in adolescents from the Mannheim Study. They found that rs1876831 moderated the effect of 
negative life events on the maximum amount of alcohol consumed per occasion and lifetime rates of heavy drinking. They did not find a $\mathrm{G} \times \mathrm{E}$ interaction for rs242938. Dahl et al. examined five SNPs in CRHR1 in a sample of alcohol dependent and control subjects. They found no significant allelic or genotypic associations with alcohol dependence, though it should be noted that the SNPs they examined did not include either rs 242938 or rs 1876831 . Although of potential interest as a moderator of heavy drinking and the risk of $\mathrm{AD}$, further evaluation of both the direct and stress moderating effects of $C R H R 1$ are needed.

\section{Discussion}

The last dozen or so years have seen a huge revision in our understanding of alcohol dependence genetics. Notwithstanding the long-known relationship of the alcohol metabolizing enzymes to AD risk in some Asian populations, the first linkage studies were initially viewed as disappointing, because they failed to provide genomewide significant results. But in the years since, the alcohol metabolizing enzyme findings have been replicated across many genes and populations beyond the initial work, and additional replicable risk loci have been identified. Only a fraction of the genetic risk is yet accounted for by known loci, but the growing number of replicable loci is encouraging. Similarly encouraging are the facts that these loci coincide with protein products that could be related to $\mathrm{AD}$ risk and that they were identified by the application of standard methods. Admittedly, though, proof that a specific variant is related to disease risk must be based on studies that take into account the function of allelic variants—-statistical evidence from linkage and association in not sufficient.

Despite the advances, there is a long way to go to fully characterize the genetic basis for $\mathrm{AD}$, and while it is likely that linkage and candidate gene or targeted association analysis will not take us the rest of the way, it is also now the case that these methods are rapidly being augmented by newer methodologies. These include, but are not limited to, GWAS, study of copy number variation (CNV) (where CNV of the alcohol-metabolizing enzymes would be an obvious possible source of risk variance), and deep sequencing of candidate loci with the goal of identifying rare risk-influencing variants. We can reasonably hope that as this technology is applied to $\mathrm{AD}$, more small-to-medium-effect risk loci will be identified.

The majority of the studies done to date have been in populations of European ancestry. An additional challenge will be to examine $\mathrm{AD}$ risk from a population perspective. This will be very important, since there are already considerable data supporting risk differences by population. Some risk alleles are already known to be population specific. It will also be of interest to determine whether particular loci are also population specific. In the context of this growing knowledge, it seems that we are likely on the threshold of major advances in our understanding of the genetics, and therefore the physiology, of alcohol dependence risk.

\section{Acknowledgments}

This work was supported by NIH grants R01 AA11330, K24 DA15105, K24 AA13736, and P50 AA12870; and the US Department of Veterans Affairs (the VA Connecticut-Massachusetts Mental Illness Research, Education and Clinical Center [MI-RECC], and the VA Connecticut Alcohol Research Center).

\section{References}

Amos CI, Wu X, Broderick P, Gorlov IP, Gu J, Eisen T, Dong Q, Zhang Q, Gu X, Vijayakrishnan J, Sullivan K, Matakidou A, Wang Y, Mills G, Doheny K, Tsai YY, Chen WV, Shete S, Spitz MR, Houlston RS. Genome-wide association scan of tag SNPs identifies a susceptibility locus for lung cancer at 15q25.1. Nat Genet. 2008; 40(5):616-622. doi: 10.1073_pnas.052716399. [PubMed: 18385676] 
Anton RF, O'Malley SS, Ciraulo DA, Cisler RA, Couper D, Donovan DM, Gastfriend DR, Hosking JD, Johnson BA, LoCastro JS, Longabaugh R, Mason BJ, Mattson ME, Miller WR, Pettinati HM, Randall CL, Swift R, Weiss RD, Williams LD, Zweben A. COMBINE Study Research Group. Combined pharmaco-therapies and behavioral interventions for alcohol dependence: the COMBINE study: a randomized controlled trial. JAMA. 2006; 295:2003-2017. [PubMed: 16670409]

Anton RF, Oroszi G, O’Malley S, Couper D, Swift R, Pettinati H, Goldman D. An evaluation of muopioid receptor (OPRM1) as a predictor of naltrexone response in the treatment of alcohol dependence: results from the combined pharmacotherapies and behavioral interventions for alcohol dependence (COMBINE) study. Arch Gen Psychiatry. 2008; 65:135-144. [PubMed: 18250251]

Arias A, Feinn R, Kranzler HR. Association of an Asn40Asp (A118G) polymorphism in the $\mu$-opioid receptor gene with substance dependence: a meta-analysis. Drug Alcohol Depend. 2006; 83:262268. [PubMed: 16387451]

Bauer LO, Covault J, Harel O, Das S, Anton R, Kranzler HR. Variation in $G A B R A 2$ predicts drinking behavior in Project MATCH subjects. Alcohol Clin Exp Res. 2007; 31:1780-1787. [PubMed: 17949392]

Berrettini W, Yuan X, Tozzi F, Song K, Francks C, Chilcoat H, Water-worth D, Muglia P, Mooser V. Alpha-5/alpha-3 nicotinic receptor subunit alleles increase risk for heavy smoking. Mol Psychiatry. 2008; 13:368-373. [PubMed: 18227835]

Bierut LJ, Madden AF, Breslau N, Johnson EO, Hatsukami D, Pomerleau OF, Swan GE, Rutter J, Bertelsen S, Fox L, Fugman D, Goate AM, Hinrichs AL, Konvicka K, Martin NG, Montgomery GW, Saccone NL, Saccone SF, Wang JC, Chase GA, Rice JP, Ballinger DG. Novel genes identified in a high-density genome wide association study for nicotine dependence. Hum Mol Genet. 2007; 16(1):24-35. [PubMed: 17158188]

Blomeyer D, Treutlein J, Esser G, Schmidt MH, Schumann G, Laucht M. Interaction between CRHR1 gene and stressful life events predicts adolescent heavy alcohol use. Biol Psychiatry. 2008; 63(2): 146-151. [PubMed: 17597588]

Caspi A, Moffitt TE. Gene-environment interactions in psychiatry: joining forces with neuroscience. Nat Rev Neurosci. 2006; 7:583-590. [PubMed: 16791147]

Caspi A, Sugden K, Moffitt TE, Taylor A, Craig IW, Harrington H, McClay J, Mill J, Martin J, Braithwaite A, Poulton R. Influence of life stress on depression: moderation by a polymorphism in the 5-HTT gene. Science. 2003; 301(5631):386-389. [PubMed: 12869766]

Clarke T-K, Treutlein J, Zimmermann US, Kiefer F, Skowronek MH, Rietschel M, Mann K, Schumann G. HPA-axis activity in alcoholism: examples for a gene-environment interaction. Addict Biol. 2007; 13(1):1-14. [PubMed: 17910738]

Covault C, Gelernter J, Hesselbrock V, Nellissery M, Kranzler HR. Allelic and haplotypic association of GABRA2 with alcohol dependence. Am J Med Genet. 2004; 129B:104-109. [PubMed: 15274050]

Covault J, Tennen H, Herman AI, Armeli S, Conner T, Cillessen AHN, Kranzler HR. Interactive effects of the serotonin transporter 5-HTTLPR polymorphism and stressful life events on college student drinking and drug use. Biol Psychiatry. 2007; 61(5):609-616. [PubMed: 16920076]

Covault J, Gelernter J, Jensen K, Anton R, Kranzler HR. Markers in the 5'-region of GABRG1 associate to alcohol dependence and are in linkage disequilibrium with markers in the adjacent GABRA2 gene. Neuropsychopharmacology. 2008; 33(4):837-848. [PubMed: 17507911]

Dick DM, Wang JC, Plunkett J, Aliev F, Hinrichs A, Bertelsen S, Budde JP, Goldstein EL, Kaplan D, Edenberg HJ, Nurnberger J Jr, Hesselbrock V, Schuckit M, Kuperman S, Tischfield J, Porjesz B, Begleiter H, Bierut LJ, Goate A. Family-based association analyses of alcohol dependence phenotypes across DRD2 and neighboring gene ANKK1. Alcohol Clin Exp Res. 2007a; 31(10): 1645-1653. [PubMed: 17850642]

Dick DM, Plunkett J, Hamlin D, Nurnberger J Jr, Kuperman S, Schuckit M, Hesselbrock V, Edenberg $\mathrm{H}$, Bierut L. Association analysis of the serotonin transporter gene with lifetime depression and alcohol dependence in the collaborative study on the genetics of alcoholism (COGA) sample. Psychiatr Genet. 2007b; 17:35-38. [PubMed: 17167343]

Drgon T, D'Addario C, Uhl GR. Linkage disequilibrium, haplotype and association studies of a chromosome $4 \mathrm{GABA}$ receptor gene cluster: candidate gene variants for addictions. Am J Med Genet B Neuropsychiatr Genet. 2006; 141B(8):854-860. [PubMed: 16894595] 
Edenberg HJ, Kranzler HR. The contribution of genetics to addiction therapy approaches. Pharmacol Ther. 2005; 108:86-93. [PubMed: 16026844]

Edenberg HJ, Jerome RE, Li M. Polymorphism of the human alcohol dehydrogenase 4 (ADH4) promoter affects gene expression. Pharmacogenetics. 1999; 9:25-30. [PubMed: 10208639]

Edenberg HJ, Dick DM, Xuei X, Tian H, Almasy L, Bauer LO, Crowe RR, Goate A, Hesselbrock V, Jones K, Kwon J, Li T-K, Nurnberger JI Jr, O’Connor SJ, Reich T, Rice M, Schuckit MA, Porjesz B, Foroud T, Begleiter H. Variations in GABRA2, encoding the $\alpha 2$ subunit of the GABAA receptor, are associated with alcohol dependence and with brain oscillations. Am J Hum Genet. 2004; 74:705-714. [PubMed: 15024690]

Edenberg HJ, Xuei X, Chen HJ, Tian H, Wetherill LF, Dick DM, Almasy L, Bierut L, Bucholz KK, Goate A, Hesselbrock V, Kuperman S, Nurnberger J, Porjesz B, Rice J, Schuckit M, Tischfield J, Begleiter H, Foroud T. Association of alcohol dehydrogenase genes with alcohol dependence: a comprehensive analysis. Hum Mol Genet. 2006; 15:1539-1549. [PubMed: 16571603]

Ehlers CL, Gilder DA, Wall TL, Phillips E, Feiler H, Wilhelmsen KC. Genomic screen for loci associated with alcohol dependence in Mission Indians. Am J Med Genet B Neuropsychiatr Genet. 2004; 129:110-115. [PubMed: 15274051]

Enoch MA, Schwartz L, Albaugh B, Virkkunen M, Goldman D. Dimensional anxiety mediates linkage of GABRA2 haplotypes with alcoholism. Am J Med Genet B Neuropsychiatr Genet. 2006; 141B(6):599-607. [PubMed: 16874763]

Enoch MA, Hodgkinson CA, Yuan Q, Albaugh B, Virkkunen M, Goldman D. GABRG1 and GABRA2 as independent predictors for alcoholism in two populations. Neuropsychopharmacology. 2009; 34:1245-1254. [PubMed: 18818659]

Fehr C, Sander T, Tadic A, Lenzen KP, Anghelescu I, Klawe C, Dahmen N, Schmidt LG, Szegedi A. Confirmation of association of the GABRA2 gene with alcohol dependence by subtype-specific analysis. Psychiatr Genet. 2006; 16:9-17. [PubMed: 16395124]

Feinn R, Nellissery M, Kranzler HR. Meta-analysis of the association of a functional serotonin transporter promoter polymorphism and alcohol dependence. Am J Med Genet B Neuropsychiatr Genet. 2005; 133B:79-84. [PubMed: 15635638]

Foroud T, Edenberg HJ, Goate A, Rice J, Flury L, Koller DL, Bierut LJ, Conneally PM, Nurnberger JI, Bucholz KK, Li TK, Hesselbrock V, Crowe R, Schuckit M, Porjesz B, Begleiter H, Reich T. Alcoholism susceptibility loci: confirmation studies in a replicate sample and further mapping. Alcohol Clin Exp Res. 2000; 24:933-945. [PubMed: 10923994]

Gelernter J, Yu Y, Weiss R, Brady K, Panhuysen C, Yang BZ, Kranzler HR, Farrer L. Haplotype spanning TTC12 and ANKK1, flanked by the DRD2 and NCAM1 loci, is strongly associated to nicotine dependence in two distinct American populations. Hum Mol Genet. 2006; 15:34983507.10.1093/hmg/ddl426 [PubMed: 17085484]

Gelernter J, Gueorguieva R, Kranzler HR, Zhang H, Cramer J, Rosenheck R, Krystal JH. the VA Cooperative Study \#425 Study Group. Opioid receptor gene (OPRM1, OPRK1, and OPRD1) variants and response to naltrexone treatment for alcohol dependence: results from the VA Cooperative Study. Alcohol Clin Exp Res. 2007; 31(4):555-563. [PubMed: 17374034]

Gelernter J, Kranzler HR, Panhuysen C, Weiss RD, Brady K, Poling J, Farrer L. Dense genomewide linkage scan for alcohol dependence in African-Americans: significant linkage on chromosome 10. Biol Psychiatry. 2009; 65:111-115. [PubMed: 18930185]

Hasin D, Aharonovich E, Liu X, Mamman Z, Matseoane K, Carr L, Li TK. Alcohol and ADH2 in Israel: Ashkenazis, Sephardics, and recent Russian immigrants. Am J Psychiatry. 2002; 159:14321434. [PubMed: 12153842]

Heath, AC.; Bucholz, KK.; Madden, PAF.; Dinwiddie, SH.; Slutske, WS.; Bierut, LJ.; Statham, DJ.; Dunne, MP.; Whitfield, JB.; Martin, NG. Genetic and environmental contributions to alcohol dependence risk in a national twin sample: consistency of findings in women and men. 1997.

Heath AC, Whitfield JB, Madden PA, Bucholz KK, Dinwiddie SH, Slutske WS, Bierut LJ, Statham DB, Martin NG. Towards a molecular epidemiology of alcohol dependence: analysing the interplay of genetic and environmental risk factors. Br J Psychiatry Suppl. 2001; 40:s33-s40. [PubMed: 11315223] 
Hettema JM, Corey LA, Kendler KS. A multivariate genetic analysis of the use of tobacco, alcohol, and caffeine in a population based sample of male and female twins. Drug Alcohol Depend. 1999; 57:69-78. [PubMed: 10617315]

Hicks BM, Krueger RF, Iacono WG, McGue M, Patrick CJ. Family transmission and heritability of externalizing disorders. Arch Gen Psychiatry. 2004; 61:922-928. [PubMed: 15351771]

Hung RJ, McKay JD, Gaborieau V, Boffetta P, Hashibe M, Zaridze D, Mukeria A, SzeszeniaDabrowska N, Lissowska J, Rudnai P, Fabianova E, Mates D, Bencko V, Foretova L, Janout V, Chen C, Goodman G, Field JK, Liloglou T, Xinarianos G, Cassidy A, McLaughlin J, Liu G, Narod S, Krokan HE, Skorpen F, Elvestad MB, Hveem K, Vatten L, Linseisen J, Clavel-Chapelon F, Vineis P, Bueno-de-Mesquita HB, Lund E, Martinez C, Bingham S, Rasmuson T, Hainaut P, Riboli E, Ahrens W, Benhamou S, Lagiou P, Trichopoulos D, Holcátová I, Merletti F, Kjaerheim K, Agudo A, Macfarlane G, Talamini R, Simonato L, Lowry R, Conway DI, Znaor A, Healy C, Zelenika D, Boland A, Delepine M, Foglio M, Lechner D, Matsuda F, Blanche H, Gut I, Heath S, Lathrop M, Brennan P. A susceptibility locus for lung cancer maps to nicotinic acetylcholine receptor subunit genes on 15q25. Nature. 2008; 452(7187):633-637. [PubMed: 18385738]

Ittiwut C, Listman JB, Mutirangura A, Malison R, Covault J, Kranzler HR, Sughondhabirom A, Thavichachart N, Gelernter J. Inter-population linkage disequilibrium (LD) patterns of GABRA2 and GABRG1 genes at the GABA cluster locus on human chromosome 4. Genomics. 2008; 91(1): 61-69. [PubMed: 17976953]

Joslyn G, Brush G, Robertson M, Smith Kalmijn J, Schuckit M, White RL. Chromosome 15q25.1 genetic markers associated with level of response to alcohol in humans. Proc Natl Acad Sci USA. 2008; 105:20368-20373. [PubMed: 19064933]

Kaufman J, Yang B-Z, Douglas-Palumberi H, Crouse-Artis M, Lipschitz D, Krystal JH, Gelernter J. Genetic and environmental predictors of early alcohol use. Biol Psychiatry. 2007; 61(11):12281234. [PubMed: 17123474]

Kendler KS, Heath AC, Neale MC, Kessler RC, Eaves LJ. A population-based twin study of alcoholism in women. JAMA. 1992; 268:1877-1882. [PubMed: 1404711]

Kendler KS, Prescott CA, Neale MC, Pedersen NL. Temperance board registration for alcohol abuse in a national sample of Swedish male twins, born 1902 to 1949. Arch Gen Psychiatry. 1997; 54:178-184. [PubMed: 9040286]

Kim SG, Kim CM, Choi SW, Jae YM, Lee HG, Son BK, Kim JG, Choi YS, Kim HO, Kim SY, Oslin DW. A mu opioid receptor gene polymorphism (A118G) and naltrexone treatment response in adherent Korean alcohol-dependent patients. Psychopharmacology (Berl). 2009; 201(4):611-618. [PubMed: 18795264]

Konishi T, Smith JL, Lin KM, Wan YJ. Influence of genetic admixture on polymorphisms of alcoholmetabolizing enzymes: analyses of mutations on the CYP2E1, ADH2, ADH3 and ALDH2 genes in a Mexican-American population living in the Los Angeles area. Alcohol Alcohol. 2003; 38:9394. [PubMed: 12554615]

Krystal JH, Cramer JA, Krol WF, Kirk GF, Rosenheck RA. Naltrexone in the treatment of alcohol dependence. N Engl J Med. 2001; 345:1734-1739. [PubMed: 11742047]

Lappalainen J, Krupitsky E, Remizov M, Pchelina S, Taraskina A, Zvartau E, Somberg LK, Covault J, Kranzler HR, Krystal J, Gelernter J. Association between alcoholism and GABRA2 in a Russian population. Alcohol Clin Exp Res. 2005; 29:493-498. [PubMed: 15834213]

Laucht M, Treutlein J, Schmid B, Blomeyer D, Becker K, Buchmann AF, Schmidt MH, Esser G, Jennen-Steinmetz C, Rietschel M, Zimmermann US, Banaschewski T. Impact of psychosocial adversity on alcohol intake in young adults: moderation by the LL genotype of the serotonin transporter polymorphism. Biol Psychiatry. 2009 [Epub ahead of print].

Long JC, Knowler WC, Hanson RL, Robin RW, Urbanek M, Moore E, Bennett PH, Goldman D. Evidence for genetic linkage to alcohol dependence on chromosomes 4 and 11 from an autosomewide scan in an American Indian population. Am J Med Genet. 1998; 81:216-221. [PubMed: 9603607]

Luczak SE, Glatt SJ, Wall TL. Meta-analysis of ALDH2 and ADH1B with alcohol dependence in Asians. Psychol Bull. 2006; 132:607-621. [PubMed: 16822169] 
Luo X, Kranzler HR, Zhao H, Gelernter J. Haplotypes at the OPRM1 locus are associated with susceptibility to substance dependence in European Americans. Am J Med Genet B Neuropsychiatr Genet. 2003; 120B:97-108. [PubMed: 12815747]

Luo X, Kranzler HR, Zuo L, Yang BZ, Lappalainen J, Gelernter J. ADH4 gene variation is associated with alcohol and drug dependence in European Americans: results from family-controlled and population-structured association studies. Pharmacogenet Genomics. 2005a; 15:755-768. [PubMed: 16220108]

Luo X, Kranzler HR, Zuo L, Lappalainen J, Yang BZ, Gelernter J. ADH4 gene variation is associated with alcohol and drug dependence in European Americans: results from HWD tests and casecontrol association studies. Neuropsychopharmacology. 2005b; 31:1085-1095. [PubMed: 16237392]

Luo X, Kranzler HR, Zuo L, Blumburg H, Wang S, Gelernter J. CHRM2 gene predisposes to alcohol dependence, drug dependence, and affective disorders: results from an extended case-control structured association study. Hum Mol Genet. 2005c; 14:2421-2434. [PubMed: 16000316]

Luo X, Kranzler HR, Zuo L, Wang S, Schork NJ, Gelernter J. Diplotype trend regression analysis of the ADH gene cluster and the ALDH2 gene: multiple significant associations with alcohol dependence. Am J Hum Genet. 2006; 78:973-987. [PubMed: 16685648]

Madden PAF, Bucholz KK, Martin NG, Heath AC. Smoking and the genetic contribution to alcoholdependence risk. Alcohol Res Health. 2000; 24:209-214. [PubMed: 15986715]

Matthews AG, Hoffman EK, Zezza N, Stiffler S, Hill SY. The role of the GABRA2 polymorphism in multiplex alcohol dependence families with minimal comorbidity: within-family association and linkage analyses. J Stud Alcohol Drugs. 2007; 68(5):625-633. [PubMed: 17690794]

Mitchell JM, Fields HL, White RL, Meadoff TM, Joslyn G, Rowbotham MC. The Asp40 mu-opioid receptor allele does not predict naltrexone treatment efficacy in heavy drinkers. J Clin Psychopharmacol. 2007; 27:112-115. [PubMed: 17224736]

Neville MJ, Johnstone EC, Walton RT. Identification and characterization of ANKK1: a novel kinase gene closely linked to DRD2 on chromosome band 11q23.1. Hum Mutat. 2004; 23:540-545. [PubMed: 15146457]

Nilsson KW, Sjoberg RL, Damberg M, Alm PO, Ohrvik J, Leppert J, Lindstrom L, Oreland L. Role of the serotonin transporter gene and family function in adolescent alcohol consumption. Alcohol Clin Exp Res. 2005; 29:564-570. [PubMed: 15834221]

Oslin DW, Berrettini W, Kranzler HR, Pettinati H, Gelernter J, Volpicelli JR, O’Brien CP. A functional polymorphism of the $\mu$-opioid receptor gene is associated with response to naltrexone treatment in alcohol-dependent patients. Neuropsychopharmacology. 2003; 28:1546-1552. [PubMed: 12813472]

Pierucci-Lagha A, Covault J, Feinn R, Nellissery M, Hernandez-Avila C, Oncken C, Morrow AL, Kranzler HR. GABRA2 alleles moderate the subjective effects of alcohol, which are attenuated by finasteride. Neuropsychopharmacology. 2005; 30:1193-1203. [PubMed: 15702134]

Porjesz B, Almasy L, Edenberg HJ, Wang K, Chorlian DB, Foroud T, Goate A, Rice JP, O'Connor SJ, Rohrbaugh J, Kuperman S, Bauer LO, Crowe RR, Schuckit MA, Hesselbrock V, Conneally PM, Tischfield JA, Li TK, Reich T, Begleiter H. Linkage disequilibrium between the beta frequency of the human EEG and a GABAA receptor gene locus. Proc Natl Acad Sci USA. 2002; 99:3729_ 3733. [PubMed: 11891318]

Prescott CA, Kendler KS. Genetic and environmental contributions to alcohol abuse and dependence in a population-based sample of male twins. Am J Psychiatry. 1999; 156:34-40. [PubMed: 9892295]

Prescott CA, Sullivan PF, Kuo PH, Webb BT, Vittum J, Patterson DG, Thiselton DL, Myers JM, Devitt M, Halberstadt LJ, Robinson VP, Neale MC, van den Oord EJ, Walsh D, Riley BP, Kendler KS. Genomewide linkage study in the Irish affected sib pair study of alcohol dependence: evidence for a susceptibility region for symptoms of alcohol dependence on chromosome 4. Mol Psychiatry. 2006; 11:603-611. [PubMed: 16534506]

Ray LA, Hutchison KE. Effects of naltrexone on alcohol sensitivity and genetic moderators of medication response: a double-blind placebo-controlled study. Arch Gen Psychiatry. 2007; 64(9): 1069-1077. [PubMed: 17768272] 
Reich T, Edenberg HJ, Goate A, Williams JT, Rice JP, Van Eerdewegh P, Foroud T, Hesselbrock V, Schuckit MA, Bucholz K, Porjesz B, Li T-K, Conneally PM, Nurnberger JI Jr, Tischfield JA, Crowe RR, Cloninger CR, Wu W, Shears S, Carr K, Crose C, Willig C, Begleiter H. Genomewide search for genes affecting the risk for alcohol dependence. Am J Med Genet. 1998; 81(3): 207-215. [PubMed: 9603606]

Schlaepfer I, Hoft NR, Collins AC, Corley RP, Hewitt JK, Hopfer CJ, Lessem J, McQueen MB, Rhee $\mathrm{SH}$, Ehringer MA. The CHRNA5/A3/B4 gene cluster variability as an important determinant of alcohol and tobacco initiation in young adults. Biol Psychiatry. 2008; 63(11):1039-1046. [PubMed: 18163978]

Schuckit MA. An overview of genetic influences in alcoholism. J Subst Abuse Treat. 2009; 36:S5S14. [PubMed: 19062348]

Soyka M, Preuss UW, Hesselbrock V, Zill P, Koller G, Bondy B. GABA-A2 receptor subunit gene (GABRA2) polymorphisms and risk for alcohol dependence. J Psychiatr Res. 2008; 42(3):184191. [PubMed: 17207817]

Swan GE, Carmelli D, Cardon LR. Heavy consumption of cigarettes, alcohol and coffee in male twins. J Stud Alcohol. 1997; 58:182-190. [PubMed: 9065896]

Thomasson HR, Edenberg HJ, Crabb DW, Mai XL, Jerome RE, Li TK, Wang SP, Lin YT, Lu RB, Yin SJ. Alcohol and aldehyde dehydrogenase genotypes and alcoholism in Chinese men. Am J Hum Genet. 1991; 48:677-681. [PubMed: 2014795]

Thorgeirsson TE, Geller F, Sulem P, Rafnar T, Wiste A, Magnusson KP, Manolescu A, Thorleifsson G, Stefansson H, Ingason A, Stacey SN, Bergthorsson JT, Thorlacius S, Gudmundsson J, Jonsson T, Jakobsdottir M, Saemundsdottir J, Olafsdottir O, Gudmundsson LJ, Bjornsdottir G, Kristjansson K, Skuladottir H, Isaksson HJ, Gudbjartsson T, Jones GT, Mueller T, Gottsäter A, Flex A, Aben KK, de Vegt F, Mulders PF, Isla D, Vidal MJ, Asin L, Saez B, Murillo L, Blondal T, Kolbeinsson H, Stefansson JG, Hansdottir I, Runarsdottir V, Pola R, Lindblad B, van Rij AM, Dieplinger B, Haltmayer M, Mayordomo JI, Kiemeney LA, Matthiasson SE, Oskarsson H, Tyrfingsson T, Gudbjartsson DF, Gulcher JR, Jonsson S, Thorsteinsdottir U, Kong A, Stefansson KA. A variant associated with nicotine dependence, lung cancer and peripheral arterial disease. Nature. 2008; 452(7187):638-642. [PubMed: 18385739]

Tidey JW, Monti PM, Rohsenow DJ, Gwaltney CJ, Miranda R Jr, McGeary JE, MacKillop J, Swift RM, Abrams DB, Shiffman S, Paty JA. Moderators of naltrexone's effects on drinking, urge, and alcohol effects in non-treatment-seeking heavy drinkers in the natural environment. Alcohol Clin Exp Res. 2008; 32(1):58-66. [PubMed: 18028530]

Treutlein J, Kissling C, Frank J, Wiemann S, Dong L, Depner M, Saam C, Lascorz J, Soyka M, Preuss UW, Rujescu D, Skowronek MH, Rietschel M, Spanagel R, Heinz A, Laucht M, Mann K, Schumann G. Genetic association of the human corticotropin releasing hormone receptor 1 (CRHR1) with binge drinking and alcohol intake patterns in two independent samples. Mol Psychiatry. 2006; 11(6):594-602. [PubMed: 16550213]

True WR, Xian H, Scherrer JF, Madden PAF, Bucholz KK, Heath AC, Eisen SA, Lyons MJ, Goldberg J, Tsuang M. Common genetic vulnerability for nicotine and alcohol dependence in men. Arch Gen Psychiatry. 1999; 56:655-661. [PubMed: 10401514]

Wang JC, Hinrichs AL, Stock H, Budde J, Allen R, Bertelsen S, Kwon JM, Wu W, Dick DM, Rice J, Jones K, Nurnberger JI Jr, Tischfield J, Porjesz B, Edenberg HJ, Hesselbrock V, Crowe R, Schuckit M, Begleiter H, Reich T, Goate AM, Bierut LJ. Evidence of common and specific genetic effects: association of the muscarinic acetylcholine receptor M2 (CHRM2) gene with alcohol dependence and major depressive syndrome. Hum Mol Genet. 2004; 13:1903-1911. [PubMed: 15229186]

Wang JC, Grucza R, Cruchaga C, Hinrichs AL, Bertelsen S, Budde JP, Fox L, Goldstein E, Reyes O, Saccone N, Saccone S, Xuei X, Bucholz K, Kuperman S, Nurnberger J Jr, Rice JP, Schuckit M, Tischfield J, Hesselbrock V, Porjesz B, Edenberg HJ, Bierut LJ, Goate AM. Genetic variation in the CHRNA5 gene affects mRNA levels and is associated with risk for alcohol dependence. Mol Psychiatry. 2008; 14:501-510. [PubMed: 18414406]

Wilhelmsen KC, Schuckit M, Smith TL, Lee JV, Segall SK, Feiler HS, Kalmijn J. The search for genes related to a low-level response to alcohol determined by alcohol challenges. Alcohol Clin Exp Res. 2003; 27(7):1041-1047. [PubMed: 12878909] 
Yang B, Kranzler HR, Zhao H, Gruen JR, Luo X, Gelernter J. Association of haplotypic variants in DRD2, ANKK1, TTC12 and NCAM1 to alcohol dependence in independent case-control and family samples. Hum Mol Genet. 2007; 16:2844-2853. [PubMed: 17761687]

Zhang H, Luo X, Kranzler HR, Lappalainen J, Yang BZ, Krupitsky E, Zvartau E, Gelernter J. Association between two $\mu$ opioid receptor gene (OPRM1) haplotype blocks and drug or alcohol dependence. Hum Mol Genet. 2006; 15:807-819. [PubMed: 16476706] 